\title{
Front Matter: Volume 7110
}

, "Front Matter: Volume 7110," Proc. SPIE 7110, Remote Sensing for Environmental Monitoring, GIS Applications, and Geology VIII, 711001 (4 November 2008); doi: 10.1117/12.817426

SPIE. Event: SPIE Remote Sensing, 2008, Cardiff, Wales, United Kingdom 


\section{PROCEEDINGS OF SPIE}

\section{Remote Sensing for Environmental Monitoring, GIS Applications, and Geology VIII}

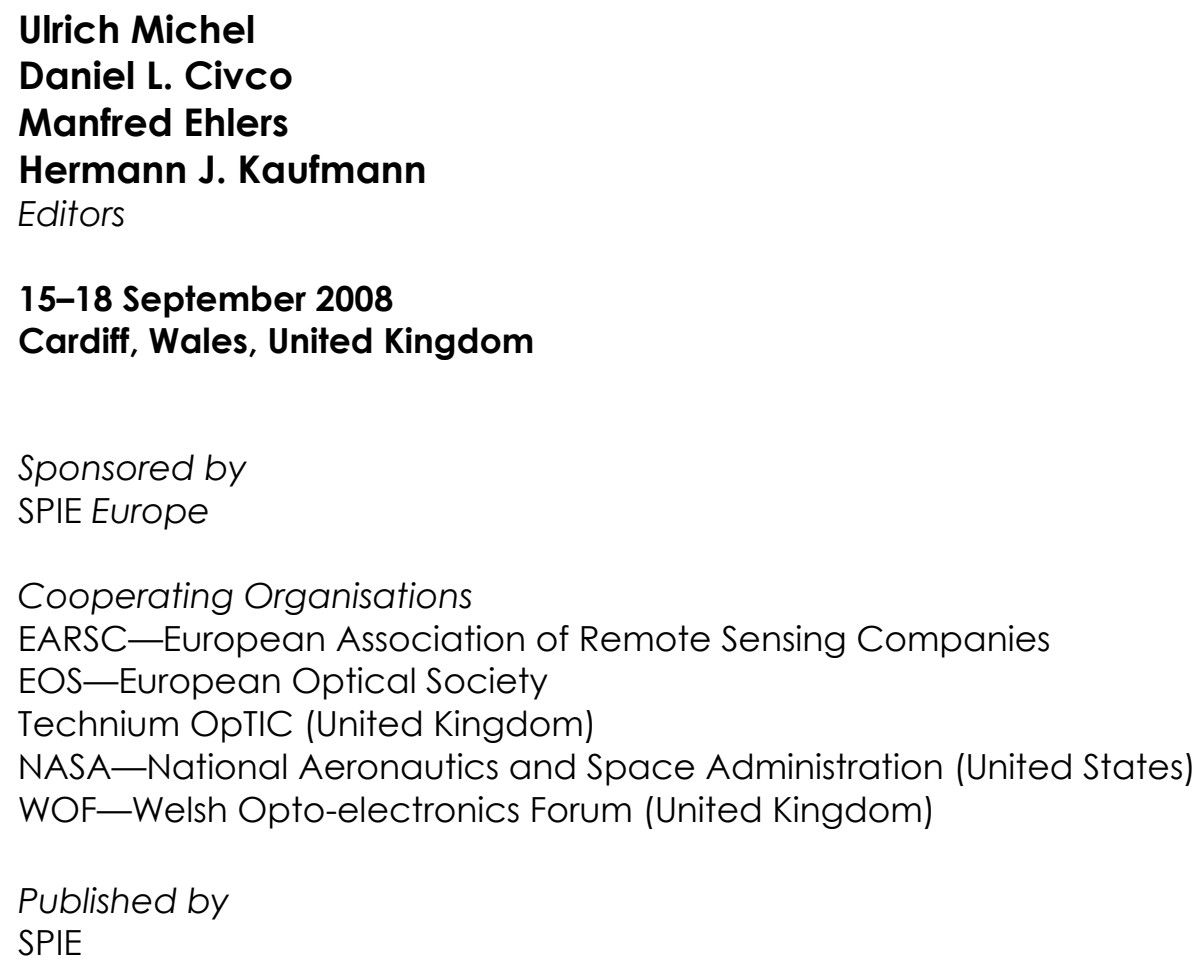

Volume 7110 
The papers included in this volume were part of the technical conference cited on the cover and title page. Papers were selected and subject to review by the editors and conference program committee. Some conference presentations may not be available for publication. The papers published in these proceedings reflect the work and thoughts of the authors and are published herein as submitted. The publisher is not responsible for the validity of the information or for any outcomes resulting from reliance thereon.

Please use the following format to cite material from this book:

Author(s), "Title of Paper," in Remote Sensing for Environmental Monitoring, GIS Applications, and Geology VIII, edited by Ulrich Michel, Daniel L. Civco, Manfred Ehlers, Hermann J. Kaufmann, Proceedings of SPIE Vol. 7110 (SPIE, Bellingham, WA, 2008) Article CID Number.

ISSN 0277-786X

ISBN 9780819473417

Published by

SPIE

P.O. Box 10, Bellingham, Washington 98227-0010 USA

Telephone +1 3606763290 (Pacific Time) · Fax +1 3606471445

SPIE.org

Copyright (c) 2008, Society of Photo-Optical Instrumentation Engineers

Copying of material in this book for internal or personal use, or for the internal or personal use of specific clients, beyond the fair use provisions granted by the U.S. Copyright Law is authorized by SPIE subject to payment of copying fees. The Transactional Reporting Service base fee for this volume is $\$ 18.00$ per article (or portion thereof), which should be paid directly to the Copyright Clearance Center (CCC), 222 Rosewood Drive, Danvers, MA 01923. Payment may also be made electronically through CCC Online at copyright.com. Other copying for republication, resale, advertising or promotion, or any form of systematic or multiple reproduction of any material in this book is prohibited except with permission in writing from the publisher. The CCC fee code is $0277-786 \mathrm{X} / 08 / \$ 18.00$.

Printed in the United States of America.

Publication of record for individual papers is online in the SPIE Digital Library.

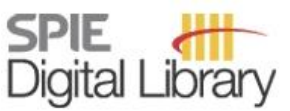

SPIEDigitalLibrary.org

Paper Numbering: Proceedings of SPIE follow an e-First publication model, with papers published first online and then in print and on CD-ROM. Papers are published as they are submitted and meet publication criteria. A unique, consistent, permanent citation identifier (CID) number is assigned to each article at the time of the first publication. Utilization of CIDs allows articles to be fully citable as soon they are published online, and connects the same identifier to all online, print, and electronic versions of the publication. SPIE uses a six-digit CID article numbering system in which:

- The first four digits correspond to the SPIE volume number.

- The last two digits indicate publication order within the volume using a Base 36 numbering

system employing both numerals and letters. These two-number sets start with $00,01,02,03,04,05$,

$06,07,08,09,0 \mathrm{~A}, \mathrm{OB} \ldots \mathrm{OZ}$, followed by 10-1Z, 20-2Z, etc.

The CID number appears on each page of the manuscript. The complete citation is used on the first page, and an abbreviated version on subsequent pages. Numbers in the index correspond to the last two digits of the six-digit CID number. 


\title{
Contents
}

\author{
xi Conference Committee
}

xv Introduction

SESSION 1 REMOTE SENSING FOR ARCHAEOLOGY, CULTURAL, AND NATURAL HERITAGE: GEOSPATIAL INFRASTRUCTURE I

711004 Old high resolution satellite images for landscape archaeology: case studies from Turkey and Iraq [71 10-03]

G. Scardozzi, Istituto Beni Archeologici e Monumentali, CNR (Italy)

711006 The biodiversity management of a marine protected area with a geographic information system in China [71 10-05]

H. Zhang, State Oceanic Administration (China) and Ocean Univ. of China (China);

W. Huang, D. Li, State Oceanic Administration (China)

SESSION 2 REMOTE SENSING FOR ARCHAEOLOGY, CULTURAL, AND NATURAL HERITAGE: GEOSPATIAL INFRASTRUCTURE II

711008 Historical and modern aerial photography for cultural heritage and environmental knowledge [7110-07]

P. Tartara, Istituto Beni Archeologici e Monumentali, CNR (Italy)

\section{SESSION 3 COASTAL REMOTE SENSING}

$71100 \mathrm{~A}$ Multitemporal spectroradiometry-guided object-oriented classification of salt marsh vegetation [71 110-09]

D. L. Civco, Univ. of Connecticut (United States); M. S. Gilmore, Wesleyan Univ. (United States); E. H. Wilson, Univ. of Connecticut (United States); N. Barrett, U.S. Dept. of Agriculture (United States); S. Prisloe, J. D. Hurd, C. Chadwick, Univ. of Connecticut (United States)

7110 OB Monitoring the invasion of Phragmites australis in coastal marshes of Louisiana, USA, using multisource remote sensing data [7110-10]

P. H. Rosso, Univ. Osnabrück (Germany); J. T. Cronin, R. D. Stevens, Lovisiana State Univ. (United States)

$71100 \mathrm{C}$ Application of remote sensing in coastal change detection after the tsunami event in Indonesia [7110-11]

H. S. Lim, M. Z. MatJafri, K. Abdullah, N. Mohd. Saleh, Univ. Sains Malaysia (Malaysia); M. S. Surbakti, Syiah Kuala Univ. (Indonesia) 
$7110 \mathrm{OE} \quad$ Urban structure analysis of mega city Mexico City using multisensoral remote sensing data [7110-13]

H. Taubenböck, German Aerospace Ctr. (Germany) and Univ. of Würzburg (Germany); T. Esch, Univ. of Würzburg (Germany); M. Wurm, German Aerospace Ctr. (Germany) and Univ. of Würzburg (Germany); M. Thiel, T. Ullmann, Univ. of Würzburg (Germany); A. Roth, German Aerospace Ctr. (Germany); M. Schmidt, German Aerospace Ctr. (Germany) and Univ. of Würzburg (Germany); H. Mehl, German Aerospace Ctr. (Germany); S. Dech, German Aerospace Ctr. (Germany) and Univ. of Würzburg (Germany)

7110 OF Building height retrieval from airborne VHR SAR imagery based on an iterative simulation and matching procedure [7110-14]

D. Brunner, Joint Research Ctr. of the European Commission (Italy) and Univ. of Trento (Italy); G. Lemoine, Joint Research Ctr. of the European Commission (Italy); L. Bruzzone, Univ. of Trento (Italy)

\section{SESSION 5 URBAN REMOTE SENSING II}

$7110 \mathrm{OH} \quad$ Reconstruction of residential buildings by detail analysis of multi-aspect InSAR data [7110-16]

A. Thiele, E. Cadario, K. Schulz, U. Thoennessen, FGAN-FOM (Germany); U. Soergel, Leibniz Univ. Hannover (Germany)

$71100 \mathrm{Ol} \quad$ Feature extraction of bridges for change detection in high resolution SAR data [71 10-17] E. Cadario, H. Gross, H. Hammer, A. Thiele, U. Thoennessen, K. Schulz, Research Institute for Optronics and Pattern Recognition (Germany); U. Soergel, Leibniz Univ. Hannover (Germany); D. J. Weydahl, Norwegian Defense Research Establishment (Norway)

7110 0J An approach to enhanced fidelity of airborne radar site-specific simulation [7110-18] V. Väisänen, J. Jylhä, I. Venäläinen, J. Vihonen, H. Perälä, A. Visa, Tampere Univ. of Technology (Finland)

7110 OK Urban land use/land cover mapping with high-resolution SAR imagery by integrating support vector machines into object-based analysis [71 10-19]

H. Hu, Y. Ban, Royal Institute of Technology (Sweden)

\section{SESSION 6 REMOTE SENSING OF HAZARDS}

$71100 \mathrm{~L}$ Integrated geospatial system for seismic hazard assessment in Vrancea area, Romania [71 10-21]

M. A. Zoran, National Institute of Research \& Development for Optoelectronics (Romania)

$71100 \mathrm{M} \quad$ Integrated remotely sensed datasets for disaster management [71 10-22]

T. McCarthy, National Univ. of Ireland, Maynooth (Ireland); R. Farrell, Institute of Microelectronics and Wireless Systems, NUIM (Ireland); A. Curtis, Univ. of Southern California (United States); A. S. Fotheringham, National Univ. of Ireland, Maynooth (Ireland) 
711000 Integration of remote sensing with GIS for grassland snow cover monitoring and snow disaster evaluating in Tibet [7110-24]

M. Gao, Institute of Agro-Resources and Regional Planning (China); S. Liu, National Disaster Reduction Ctr. (China); Z. Qin, Institute of Agro-Resources and Regional Planning (China) and Nanjing Univ. (China); J. Qiu, B. Xu, W. Li, X. Yang, Institute of Agro-Resources and Regional Planning (China); J. Li, Nanjing Univ. (China)

\section{SESSION 7 ENVIRONMENTAL MONITORING: POLLUTION}

$71100 Q$ The application of hyperspectral image techniques on MODIS data for the detection of oil spills in the RSA [71 $110-26]$

F. Alawadi, Regional Organization for the Protection of Marine Environment (Kuwait);

C. Amos, Univ. of Southampton (United Kingdom); V. Byfield, National Oceanography Ctr. (United Kingdom); P. Petrov, Regional Organization for the Protection of Marine Environment (Kuwait)

$71100 R \quad$ Geospatial modelling of metocean and environmental ancillary data for the oil spill probability assessment in SAR images [71 10-27]

O. Müllenhoff, B. Bulgarelli, G. Ferraro, M. Perkovic, K. Topouzelis, V. Sammarini, European Commission Joint Research Ctr. (Italy)

7110 OS Numerical simulation of the pollutant transportation in Chinese Hangzhou Bay with QSCAT/NCEP wind data [71 $110-28]$

N. Li, Tianjin Univ. (China) and State Oceanic Administration (China); Z. Mao, State Oceanic Administration (China); Q. Zhang, Tianjin Univ. (China)

\section{SESSION 8 DATA FUSION}

7110 0T Quality assessment for multitemporal and multisensor image fusion [7110-29]

M. Ehlers, S. Klonus, Univ. of Osnabrueck (Germany)

$71100 \mathrm{U}$ Multidirectional decomposition and directional contrast based remote sensing images fusion [71 10-32]

Y. Na, Xidian Univ. (China); M. Ehlers, Osnabrueck Univ. (Germany); J. Meng, Z. Yang, Xidian Univ. (China)

\section{SESSION 9 LAND USE AND LAND COVER}

7110 OV Finnish CORINE 2006 project: determining changes in land cover in Finland between 2000 and 2006 [71 10-33]

M. Haakana, Finnish Forest Research Institute Metla (Finland); S. Hatunen, P. Härmä, M. Kallio, SYKE-Finnish Environment Institute (Finland); M. Katila, Finnish Forest Research Institute Metla (Finland); T. Kiiski, SYKE-Finnish Environment Institute (Finland); K. Mäkisara, J. Peräsaari, Finnish Forest Research Institute Metla (Finland); H. Piepponen, R. Repo, R. Teiniranta, SYKE-Finnish Environment Institute (Finland); E. Tomppo, Finnish Forest Research Institute Metla (Finland); M. Törmä, SYKE-Finnish Environment Institute (Finland) 
$7110 \mathrm{OW}$ Classification of natural areas in northern Finland using remote sensing images and ancillary data [7110-34]

S. Hatunen, P. Härmä, M. Kallio, M. Törmä, SYKE-Finnish Environment Institute (Finland)

7110 OY Knowledge-based land use mapping integrated GIS and time-series MODIS NDVI data in Lhasa River basin, Tibet [7110-36]

S. Zhang, Institute of Genetics and Developmental Biology (China) and Graduate Univ., Chinese Academy of Sciences (China); Y. Lei, L. Zheng, H. Li, Institute of Genetics and Developmental Biology (China); T. Tang, Z. Wang, Institute of Genetics and Developmental Biology (China) and Graduate Univ., Chinese Academy of Sciences (China)

\section{SESSION 10 GEOLOGICAL REMOTE SENSING I}

711010 EO-1 Hyperion and ALI bands simulation to Landat $7 \mathrm{ETM}^{+}$bands for mineral mapping of Milos Island [71 10-37]

K. G. Nikolakopoulos, P. I. Tsombos, Institute of Geology \& Mineral Exploration (Greece);

G. Aim. Skianis, D. A. Vaiopoulos, Univ. of Athens (Greece)

711011 Tunable mechanical monolithic sensor with interferometric readout for low frequency seismic noise measurement [7110-38]

F. Acernese, Univ. degli Studi di Salerno (Italy) and INFN, Sezione di Napoli (Italy);

R. De Rosa, G. Giordano, Univ. degli Studi di Napoli Federico II (Italy) and INFN, Sezione di Napoli (Italy); R. Romano, F. Barone, Univ. degli Studi di Salerno (Italy) and INFN, Sezione di Napoli (Italy)

711012 Spatial database for the management of "urban geology" geothematic information: the case of Drama City, Greece [7110-39]

E. Pantelias, A. D. Zervakou, P. I. Tsombos, K. G. Nikolakopoulos, Institute of Geology \& Mineral Exploration (Greece)

\section{SESSION 11 GEOLOGICAL REMOTE SENSING II}

711014 Toward new methodology for improvement of topographic and anisotropic correction of desert bare soil [7110-41]

A. I. Alomran, General Commission for Survey (Saudi Arabia); M. J. McCullagh, Univ. of Nottingham (United Kingdom)

711015 Integrated and multiscale NDT for the study of architectural heritage [71 10-42] L. Nuzzo, Keele Univ. (United Kingdom); N. Masini, Istituto Beni Archeologici e Monumentali, CNR (Italy); E. Rizzo, R. Lasaponara, Istituto di Metodologie per l'Analisi Ambientale, CNR (Italy)

711016 Evaluation of adequacy of DEM level-1 as an alternative to level-2: in a context of a case study for radiometric normalization of desert bare soil in Saudi Arabia [71 10-43]

A. I. Alomran, General Commission for Survey (Saudi Arabia); M. J. McCullagh, Univ. of Nottingham (United Kingdom) 
711017 Ring structure characteristics of South Ordos basin and its control factors in the deep [7110-44]

F. Yang, Shandong Univ. of Science and Technology (China); B. XU, LMU Muenchen (Germany); H. Li, Shandong Univ. of Science and Technology (China) and Shandong Geologic Institute (China); Z. Yang, Shandong Univ. of Science and Technology (China)

\section{SESSION 12 REMOTE SENSING MODELING}

711019 A satellite AOT derived from the ground sky transmittance measurements [7110-47] H. S. Lim, M. Z. MatJafri, K. Abdullah, K. C. Tan, C. J. Wong, N. Mohd. Saleh, Univ. Sains Malaysia (Malaysia)

$71101 \mathrm{~A}$ Retrieving spatial-temporal variation of land surface temperature in Tibetan Plateau for the years 2005-2006 from MODIS satellite data [71 10-48]

M. Gao, Institute of Agro-Resources and Regional Planning (China); Z. Qin, Institute of Agro-Resources and Regional Planning (China) and Nanjing Univ. (China); J. Qiu, Institute of Agro-Resources and Regional Planning (China); S. Liu, National Disaster Reduction Ctr. (China); B. Xu, W. Li, X. Yang, Institute of Agro-Resources and Regional Planning (China)

\section{SESSION 13 NOVEL REMOTE SENSING/GIS APPLICATIONS}

7110 1B Geoinformatics paves the way for a zoo information system (Invited Paper) [7110-49]

U. Michel, Univ. of Osnabrueck (Germany)

7110 1C Aviation obstacle auto-extraction using remote sensing information [71 10-50] N. Zimmer, Jeppesen GmbH (Germany); W. Lugsch, D. Ravenscroft, Jeppesen (United States); J. Schiefele, Jeppesen GmbH (Germany)

\section{POSTER SESSION}

7110 1D Historical aerial photographs: the territory of Caere [7110-51]

P. Tartara, Istituto Beni Archeologici e Monumentali, CNR (Italy)

$71101 \mathrm{E}$ Evaluation of impacts of ecological water conveyances on hydrological processes and land cover in Tarim River basin, China, using groundwater levels and MODIS vegetation indices [71 10-52]

Q. Shen, J. XU, East China Normal Univ. (China); Y. Lei, Institute of Genetics and Developmental Biology (China)

$71101 \mathrm{~F}$ Drought remote sensing monitoring based on the Modified Perpendicular Drought Index method [7110-55]

H. Zhang, Nanjing Univ. of Information Science \& Technology (China), Meteorological Bureau of XinXiang (China), and Henan Institute of Meteorology (China); H. Chen, Henan Institute of Meteorology (China); S. Shen, Nanjing Univ. of Information Science \& Technology (China); C. Zou, Henan Institute of Meteorology (China) 
$71101 G$ Removing long-term errors from the AVHRR observation based on Normalized Difference Vegetation Index (NDVI) [71 10-57]

Md. Z. Rahman, LaGuardia Community College, CUNY (United States); L. Roytman, A. Rahman, City College, CUNY (United States); F. Kogan, National Oceanic and Atmospheric Administration (United States); R. Jesmin, King's College London (United Kingdom)

$7110 \mathrm{1H}$ The research of East Chinese seacoast remote sensing image and vector data fusion [7110-58]

H. Zhang, Z. Mao, State Oceanic Administration (China); X. Liu, Haerbing Applied Vocational and Technical College (China)

711011 SPOT/VEGETATION NDVI reconstruction and season monitoring in China [7110-59] Z. Chen, State Oceanic Administration (China) and Zhejiang Univ. (China); Z. Mao, J. Zou, State Oceanic Administration (China); Q. Ma, Renmin Univ. of China (China); X. Deng, Anhui Institute of Meteorology (China)

$71101 \mathrm{~K}$ Study of snow cover area and depth variation of the Tianshan Mountains [7110-62] J. Tao, Q. Qin, Peking Univ. (China)

711010 Identification of mafic-ultramafic rocks using fuzzy logic classification of airborne geophysical data in the Anapu-Tuerê region, Brazilian Amazon [71 10-66]

C. de C. Carneiro, A. P. Crósta, Univ. of Campinas (Brazil); A. M. Silva, Univ. of Brasília

(Brazil); C. E. de M. Barros, Federal Univ. of Paraná (Brazil)

$71101 R \quad$ Reflectance properties and physiological responses of bulrush in wetland parks to heavy metal contamination [71 10-70]

Q. Cheng, D. Tang, X. Wu, Zhejiang Gongshang Univ. (China)

$71101 \mathrm{~T}$ Multisource remote sensing archaeology of the Ancient Canal in Zhejiang, China [7110-72] Q. Cheng, X. Wu, Zhejiang Gongshang Univ. (China)

$71101 \mathrm{U}$ The spectral and image characteristics of vegetation in the presence of heavy metals in southern China [7110-73]

F. Yang, Shandong Univ. of Science and Technology (China); N. Li, LMU Muenchen (Germany); G. Zhou, C. Song, Shandong Univ. of Science and Technology (China); Q. Li, Remote Sensing Application Institute (China)

$71101 \mathrm{~V}$ Calculating geomorphic indices in SE Asia using a SRTM derived DEM: a worked example from West Sulawesi, Indonesia [71 1 $10-75]$

F. Vecchiotti, Univ. of London (United Kingdom)

$71101 \mathrm{Y}$ Correction of reflectance characteristics of chosen natural and anthropogenic materials for an airborne laser scanning system [7110-78]

M. Kaszczuk, M. Zygmunt, J. Mierczyk, Military Univ. of Technology (Poland)

711012 Seismic waves velocity measurement with laser interferometric sensors [7110-79]

F. Acernese, R. Romano, F. Barone, Univ. degli Studi di Salerno (Italy) and INFN, Sezione di Napoli (Italy) 
711020 Hybrid control and acquisition system for remote control systems for environmental monitoring [71 10-80]

F. Garufi, Univ. degli Studi di Napoli Federico II (Italy) and INFN, Sezione di Napoli (Italy);

F. Acernese, Univ. degli Studi di Salerno (Italy) and INFN, Sezione di Napoli (Italy); A. Boiano, Sezione di Napoli, Complesso Univ. di Monte S. Angelo, INFN (Italy); R. De Rosa, Univ. degli Studi di Napoli Federico II (Italy) and INFN, Sezione di Napoli (Italy); R. Romano, F. Barone, Univ. degli Studi di Salerno (Italy) and INFN, Sezione di Napoli (Italy)

711021 Multispectral and multitemporal satellite data fusion for coastal zone dynamics assessment [7110-81]

L. F. V. Zoran, C. Ionescu Golovanov, Univ. Politechnica of Bucharest (Romania);

M. A. Zoran, National Institute of R\&D for Optoelectronics (Romania)

711022 Merging radar data with geographic data for visual land clutter source recognition [71 10-82]

H. Perälä, J. Jylhä, M. Väilä, A. Visa, Tampere Univ. of Technology (Finland)

711023 Monitoring rangeland plant community composition using spectral mixture analysis of hyperspectral remote sensing data [7110-83]

N. Rochdi, P. Eddy, K. Staenz, J. Zhang, C. Lutz, Alberta Terrestrial Imaging Ctr. (Canada)

711024 Satellite-based enhancement of archaeological marks through data fusion techniques

[71 10-86]

R. Lasaponara, Institute of Methods for Environmental Analysis, CNR (Italy); N. Masini, Institute of Archaeological and Cultural Heritage, CNR (Italy); B. Aiazzi, Institute of Applied Physics Nello Carrara, CNR (Italy); L. Alparone, Univ. of Florence (Italy); S. Baronti, Institute of Applied Physics Nello Carrara, CNR (Italy)

Author Index 
Downloaded From: https://www.spiedigitallibrary.org/conference-proceedings-of-spie on 26 Apr 2023

Terms of Use: https://www.spiedigitallibrary.org/terms-of-use 


\title{
Conference Committee
}

\author{
Symposium Chairs
}

Guido D'Urso, Università degli Studi di Napoli Federico II (Italy)

Steven P. Neeck, NASA Headquarters (United States)

Conference Chairs

Ulrich Michel, Institute for Geoinformatics and Remote Sensing, University of Osnabrueck (Germany)

Daniel L. Civco, University of Connecticut (United States)

\section{Conference Cochairs}

Manfred Ehlers, Universität Osnabrück (Germany)

Hermann J. Kaufmann, GeoForschungsZentrum Potsdam e.V. (Germany)

\section{Program Committee}

Peggy Agouris, University of Maine (United States)

Costas Armenakis, Natural Resources Canada (Canada)

Eyal Ben-Dor, Tel-Aviv University (Israel)

Thomas Blaschke, Paris-Lodron-Université Salzburg (Austria)

Tilman U. Bucher, Deutsches Zentrum für Luft- und Raumfahrt e.V. (Germany)

Nickolas L. Faust, Georgia Institute of Technology (United States)

Garik Gutman, NASA Headquarters (United States)

Bernt E. Johansen, NORUT Information Technology Ltd. (Norway)

Carsten Jürgens, Ruhr-Universität Bochum (Germany)

Martin Kappas, GWDG (Germany)

Rosa Lasaponara, Istituto di Metodologie per l'Analisi Ambientale, CNR (Italy)

Marguerite M. Madden, The University of Georgia (United States)

Derya Maktav, Istanbul Technical University (Turkey)

Nicola Masini, Istituto Beni Archeologici e Monumentali, CNR (Italy)

Josiane Masson, European Commission (Italy)

Matthias S. Moeller, Arizona State University (United States)

Konstantinos G. Nikolakopoulos, Institute of Geology \& Mineral Exploration (Greece)

loana A. Oltean, University of Exeter (United Kingdom)

Florian Savopol, Natural Resources Canada (Canada)

Michael E. Schaepman-Strub, Wageningen University (Netherlands)

Karsten Schulz, FGAN-FOM (Germany) 
Wenzhong Shi, The Hong Kong Polytechnic University

(Hong Kong China)

Alexander Siegmund, Pädagogische Hochschule Heidelberg (Germany)

Karl Staenz, University of Lethbridge and Alberta Terrestrial Imaging Center (Canada)

Josef Strobl, Paris-Lodron-Universität Salzburg (Austria)

Lars Tufte, BfG-en (Germany)

John L. van Genderen, International Institute for Aerospace Survey (Netherlands)

Christiane H. Weber, Université Louis Pasteur (France)

\section{Session Chairs}

1 Remote Sensing for Archaeology, Cultural and Natural Heritage:

Geospatial Infrastructure I

Rosa Lasaponara, Istituto di Metodologie per l'Analisi Ambientale, CNR (Italy)

2 Remote Sensing for Archaeology, Cultural, and Natural Heritage: Geospatial Infrastructure II

Rosa Lasaponara, Istituto di Metodologie per l'Analisi Ambientale, CNR (Italy)

3 Coastal Remote Sensing

Daniel L. Civco, University of Connecticut (United States)

$4 \quad$ Urban Remote Sensing I

Dominik Brunner, Joint Research Center of the European Commission (Italy)

$5 \quad$ Urban Remote Sensing II

Karsten Schulz, Forschungsgesellschaft für Angewandte

Naturwissenschaften e.V. (Germany)

6 Remote Sensing of Hazards

Maria A. Zoran, National Institute of Research and Development for Optoelectronics (Romania)

7 Environmental Monitoring: Pollution

Pablo H. Rosso, Universität Osnabrück (Germany)

8 Data Fusion

Manfred Ehlers, Universität Osnabrück (Germany)

9 Land Use and Land Cover

Markus Törmä, SYKE_Finnish Environment Institute (Finland) 
10 Geological Remote Sensing I

Konstantinos G. Nikolakopoulos, Institute of Geology \& Mineral Exploration (Greece)

11 Geological Remote Sensing II

Fabrizio Barone, Instituto Nazionale di Fisica Nucleare (Italy)

12 Remote Sensing Modeling

Gennadii A. Kolotkov, Institute of Atmospheric Optics (Russia)

13 Novel Remote Sensing/GIS Applications

Ulrich Michel, Institute for Geoinformatics and Remote Sensing, University of Osnabrueck (Germany) 
Downloaded From: https://www.spiedigitallibrary.org/conference-proceedings-of-spie on 26 Apr 2023

Terms of Use: https://www.spiedigitallibrary.org/terms-of-use 


\section{Introduction}

These proceedings contain 53 papers that were presented at the SPIE Conference on 'Remote Sensing for Environmental Monitoring, GIS Applications, and Geology.' The conference took place in Cardiff, Wales, 15-18 September 2008. It was the eighth conference with this topic after its inauguration in Toulouse, France, in 2001.

The conference sessions with presented papers and interactive posters were grouped into the following themes: remote sensing for archaeology, cultural, and natural heritage geospatial infrastructure; coastal remote sensing; urban remote sensing; remote sensing of hazards; environmental monitoring: pollution; data fusion; land use and land cover; geological remote sensing; remote sensing modeling, and novel remote sensing/GIS applications. Lively discussions often continued into the coffee breaks. Although the session topics seemed rather diverse, there was a common thread to many papers, i.e., application of remotely sensed data for the protection of our environment and its integration with Geographic Information Systems (GIS). Our conference is the only one in SPIE's International Symposium on Remote Sensing that covers GIS. There was strong support from the audience to continue these themes for future conferences.

The paper submission and review process were again perfectly organized by the SPIE staff. We like to thank the SPIE staff onsite for their responsiveness and support. We are also grateful to our cochairs, Manfred Ehlers and Hermann Kaufmann, and the program committee for their help in the reviewing and session compilation process.

\section{Ulrich Michel Daniel L. Civco}


Downloaded From: https://www.spiedigitallibrary.org/conference-proceedings-of-spie on 26 Apr 2023

Terms of Use: https://www.spiedigitallibrary.org/terms-of-use 